\title{
KEKERASAN TERHADAP ANAK RESPON PEKERJAAN SOSIAL
}

\author{
Edi Suharto \\ Direktur Bidang Kesejahteraan Sosial Anak Kementerian Sosial \\ Republik Indonesia-Jakarta \\ Email: edsocialpolicy@gmail.com
}

\begin{abstract}
Violence against child become national and global issue. In some developed countries, violence against child emotionally, physically, and sexually happens. The same thing also happens in Indonesia so efforts to protect children become a crucial issue, especially for those who are vulnerable. This paper shows that boys are more vulnerable than girls. In case of sexual abuse for example, one of the 12 boys are vulnerable to sexual abuse than girls who have a ratio of 1:19. Unfortunately, most children do not know about social services related to child abuse. Perpetrators of violence are dominated by people who are nearby and familiar with them. For protection of children, its system needs to beresponded to byrelevantprofessioninsocialwork and it becomeconstitutional mandate.
\end{abstract}

Keywords: Violence against children, Social work, and Child protection.

\begin{abstract}
ABSTRAK
Kekerasan anak telah menjadi isu nasional dan global.Di beberapa negara maju, kekerasan pada anak pun telah terjadi seperti kekerasan emosional, fisik dan seksual. Di Indonesia, kekerasan demi kekerasan juga telah terjadi dan menjadi "kasus yang biasa" sehingga upaya perlindungan kepada anak menjadi masalah yang krusial khususnya bagi mereka yang rentan. Tulisan ini menunjukkan bahwa anak lakilaki lebih rentan dibandingkan dengan anak perempuan.Sebagai contoh kekerasan seksual, bahwa satu dari 12 anak laki-laki rentan mengalami kekerasan seksual dibandingkan dengan anak perempuan yang memiliki rasio 1:19. Sayangnya, sebagian besar anak belum mengetahui tentang layanan sosial terkait kekerasan anak.Pelaku kekerasan didominasi oleh orang-orang terdekat yang sudah mengenal korban.Untuk itu, sistem perlindungan kepada anak perlu direspon oleh profesi yang relevan pada pekerjaan sosial yang menjadi amanah konstitusi.
\end{abstract}

Kata Kunci: Kekerasan anak, Pekerjaan sosial, dan Perlindungan anak 


\section{PENGANTAR}

Sebagai bangsa yang menjunjung tinggi hak asasi manusia (HAM) segala bentuk kekerasan harus dihapuskan dari kehidupan umat manusia. Kekerasan dalam bentuk apapun dan yang menimpa pihak manapun. Untuk menjadi bangsa yang maju kekerasan terhadap anak tidak boleh dibiarkan terjadi. Sayangnya, kekerasan demi kekerasan terjadi di Indonesia, terutama kekerasan yang terjadi pada anak. Sebagian besar anak di Indonesia hidup dalam bayang-bayang kekerasan yang menimbulkan trauma mendalam. Padahal, anak adalah generasi penerus bangsa. Kehidupan anak saat ini adalah potret kehidupan bangsa di masa mendatang. Jika kekerasan demi kekerasan dibiarkan terjadi, sama artinya dengan menciptakan masa depan yang suram bagi kehidupan bangsa di masa yang akan datang.

Kekerasan terhadap anak di Indonesia merupakan fakta yang tidak dapat diabaikan. Begitu banyak pemberitaan di media massa baik elektronik maupun cetak yang menyangkut fenomena kekerasan terhadap anak ini. Baik itu kekerasan secara fisik maupun non-fisik. Sayangnya kekerasan dianggap sebagai hal yang wajar.Kewajaran ini bisa dimengerti karena setiap sesuatu yang terjadi secara berulang-ulang bisa dianggap benar. Ini menjadi semacam wacana (discourse) umum di tengah masyarakat.Oleh karena itu, meminjam istilah Michael Foucault perlu ada wacana tandingan (counter-discourse) yang berfungsi sebagai penyeimbang sekaligus lonceng peringatan.

Seperti dalam tayangan televisi, masyarakat kerap dipertontonkan acara-acara yang menampilkan kekerasan secara terbuka. Kekurangan dalam bentuk fisik sering menjadi bahan ejekan, cemoohan dan tertawaan. Ironisnya, masyarakat kita justru merasa terhibur. Terbukti acara-acara yang menampilkan kekerasan semacam ini menjadi program favorit dengan rating yang sangat tinggi ditunjukkan dengan waktu penayangannya pada jam-jam khusus (prime time). Tentu tidak boleh membiarkan ini terus terjadi, sebab jika dibiarkan maka kekerasan akan menjadi bagian dari kehidupan. Begitu pula dengan kekerasan terhadap anak akan dianggap sebagai sesuatu yang wajar meskipun hal itu melanggar hak-hak kemanusiaan seseorang.

Pencegahan ataupun penanganan terhadap kekerasan anak bisa dilakukan dengan efektif apabila mengetahui bagaimana sesungguhnya yang dimaksud dengan kekerasan terhadap anak tersebut. Tulisan ini fokus kepada masalah bagaimana sesungguhnya yang dimaksud dengan kekerasan terhadap anak itu.Baik itu berkaitan dengan bentuk, pelaku, maupun prevalensinya. Selain itu, tulisan ini juga membahas bagaimana respon yang seharusnya dapat dilakukan oleh profesi pekerjaan sosial dalam menghadapi kekerasan anak.

Berkaitan dengan masalah di atas, tulisan ini bertujuan untuk menampilkan faktafakta mengenai kekerasan terhadap anak. Fakta-fakta tersebut menyangkut model, kategori korban, bahkan siapa pelaku kekerasan. Fakta-fakta ini terutama merujuk kepada hasil Survey Terhadap Kekerasan Anak (SKTA) tahun 2013 yang diselenggarakan oleh Kementerian Sosial dan Kementerian Pemberdayaan Perempuan dan Perlindungan Anak dengan dukungan BAPPENAS (Badan Perencanaan Pembangunan Nasional), Badan Pusat Statistik (BPS), dan Centers for Desease Control and Prevention, USA. Ulasan yang merujuk pada fakta-fakta riil dalam masyarakat dimaksudkan agar semua menjadi tahu bahkan kekerasan terhadap anak bukanlah suatu peristiwa yang tidak berdasar, tetapi memang betul-betul terjadi di tengah-tengah masyarakat. Semua dapat sadar dan tergugah untuk bersama-sama mencegah terjadinya kekerasan yang mungkin dapat menimpa anak-anak kita kapan saja dan di mana saja.

Tulisan ini bersifat kualitatif dengan menjadikan hasil SKTA tahun 2013 sebagai sumber data primer. Sumber data lainnya diambil dari berbagai sumber baik referensi berupa buku yang berkaitan dengan kekerasan (anak) maupun pemberitaan media massa yang berkaitan dengan tema. Dari data primer maupun skunder tersebut dilakukan 
analisis secara mendalam untuk mengetahui seperti apa kekerasan terhadap anak tersebut dan bagaimana respon pekerjaan sosial dalam menghadapinya.

Kajian kekerasan pada anak terutama terhadap kondisi termutakhir belum banyak dilakukan. Jikapun ada, masih bersifat lokalistik dan tidak menggunakan perspektif pekerjaan sosial (social work). Misalnya penelitian tentang Trafiking Perempuan dan Anak: Penanggulangan Komprehensif Studi Kasus Sulawesi Utara,oleh L.M. Gandhi Lapian dan Hetty A. Geru (editor) yang secara lokal melakukan penelitian di Sulawesi Utara. Sunarto (2009) dalam Televisi, Kekerasan dan Perempuan mengkaji kekerasan berkaitan dengan perempuan. Ringkasnya, kajian tentang kekerasan pada anak khususnya pada kondisi termutakhir belum dilakukan.Untuk itulah tulisan ini dibuat untuk memberikan gambaran secara mutakhir terkait kekerasan pada anak dalam perspektif pekerjaan sosial.

Pekerjaan sosial di sini dimaksudkan sebagai disiplin ilmu yang setara dengan disiplin ilmu lain dan bukan profesi amal yang banyak dipahami masyarakat.Beberapa perguruan tinggi telah menyelenggarakan pendidikan pekerjaan sosial Baik strata satu (s1), strata dua (s2) maupun doctoral seperti pendidikan kedokteran menghasilkan dokter, pendidikan-guru, dan hukumpengacara, maka pekerjaan sosial menghasilkan profesi pekerja sosial. Pekerja sosial berperan mengatasi masalah sosial. Di sinilah keterkaitan pekerjaan sosial dalam melakukan respon pada kasus kekerasan anak.

\section{PEMBAHASAN \\ Kekerasan Anak sebagai Isu Global}

Kekerasan anak telah menjadi isu global. Meskipun karakteristik kekerasan terhadap anak secara global kadang-kadang berbeda dengan kekerasan anak di Indonesia. Sebagai isu global, ini mengindikasikan bahwa kekerasan anak telah menjadi masalah yang serius dan harus menjadi perhatian semua pihak. Tidak hanya perhatian dari profesi pekerjaan sosial saja, tetapi juga stakeholders lain yang memiliki keterkaitan dengan kesejahteraan anak. Tanpa adanya dukungan dari berbagai stakeholders ini maka kekerasan terhadap anak mustahil dapat dihapuskan.

Terkait isu global, data dari World Health Organization (2010) menunjukkan bahwa sekitar $20 \%$ perempuan dan $5-10 \%$ laki-laki pernah mengalami kekerasan seksual pada suatu ketika semasa masih anakanak. Bahkan di negara adidaya Amerika Serikat yang dikenal menjunjung tinggi kebebasan dan hak asasi manusia kekerasan terhadap anak adalah sesuatu yang sudah umum terjadi. Faktanya menunjukkan 36,7\% anak mengalami serangan tanpa senjata dan cedera; $14,9 \%$ mengalami serangan dengan senjata dan mengalami cedera; $6.1 \%$ mengalami kekerasan seksual; $10.2 \%$ menjadi korban penganiayaan; $1.4 \%$ menjadi korban kekerasan pacaran; 9.8\% menjadi saksi mata pada kasus kekerasan dalam rumah tangga; dan terakhir 19.2\% menjadi saksi mata pada serangan yang terjadi di masyarakat (Finkelhor et.al., 2009).

Sementara itu, kekerasan yang dialami anak laki-laki maupun perempuan khususnya yang terjadi di dalam rumah di berbagai negara cukup bervariasi. Baik itu perlakuan yang salah (abuse) secara fisik maupun pengalaman seorang anak yang mengalami trauma dengan bentuk yang berbedabeda.Penelitian Emma Fulu (2014) terkait perlakuan yang salah ini menunjukkan bahwa prosentase tertinggi ada pada negara Papua Nugini (PNG) (67\% laki-laki dan 49\% perempuan) disusul berturut-turut Indonesia (Jayapura) (50\% laki-laki), Kamboja (50\% perempuan dan $45 \%$ laki-laki), Srilanka (38\% laki-laki dan $21 \%$ perempuan), Indonesia (urban) (33\% laki-laki), China (26\% laki-laki dan $12 \%$ perempuan), Bangladesh (urban) (19\% laki-laki), Indonesia (pedalaman) (18\% laki-laki), dan Bangladesh (pedalaman) (13\% laki-laki).

Data ini yang menarik adalah di beberapa negara justru korban yang terbanyak adalah pihak laki-laki dibandingkan dengan perempuan. Padahal umumnya masyarakat menganggap perempuan lebih rentan daripada 
laki-laki. Menurut Fulu (2014) faktor ketatnya kontrol atau penjagaan terhadap anak perempuan justru menjadi pemicu rentannya anak laki-laki dalam menjadi korban kekerasan ini.Terutama ini terjadi di negaranegara Asia.Ketika kontrol keluarga terfokus kepada anak perempuan, anak laki-laki justru luput dari pengawasan sehingga kekerasan kerap menimpa anak laki-laki.

\section{Kekerasan Anak di Indonesia}

Tidak jauh berbeda dengan kondisi anak pada konteks global, di Indonesia nasib anak bangsa sangat memprihatinkan. Jumlah anak di Indonesia pada 2012 adalah 84 juta dari keseluruhan penduduk yang berjumlah 240 juta jiwa. Dari jumlah tersebut anakanak yang hidup dalam jeratan kemiskinan berjumlah 44,3 juta dengan uang kurang dari 2 dollar per hari, sedangkan lainnya (30,2 juta) anak hidup dengan lebih dari 2 dollar per hari (UNICEF, 2014). Anak dalam kondisi kemiskinan ini tentu membutuhkan perhatian baik dari pemerintah maupun dari masyarakat guna mengantisipasi kekerasan lebih lanjut yang mungkin saja sangat rentan dialami.

Kerentanan anak Indonesia dapat digambarkan antara lain: (1) setiap tiga menit satu anak Indonesia meninggal sebelum mencapai usia 5 tahun dimana sekitar 500.000 anak per tahun dari akibat penyakit yang sebenarnya bisa dicegah; (2) sekitar 1,8 juta anak tidak diimunisasi secara lengkap dan parahnya ini adalah yang ke-3 tertinggi di dunia;(3) $59 \%$ anak Indonesia tidak mempunyai akta kelahiran; (4) sekitar 2,3 juta anak berusia 7-15 tahun mengalami putus sekolah;(5) sekitar 7\% anak Indonesia dengan usia 5-17 tahun mengalami eksploitasi ekonomi karena terlibat menjadi pekerja anak (UNICEF, 2014).

Dalam lima tahun terakhir ini, masyarakat juga disuguhkan dengan berbagai pemberitaan media massa terutama menyangkut kekerasan seksual pada anak. Mulai dari kasus Bekuni alias babe (48) yang melakukan pembunuhan 7 anak jalanan disertai dengan kekerasan seksual hingga kekerasan seksual yang menimpa beberapa orang siswa di se- kolah internasional yang cukup tersohor di Jakarta yakni Jakarta International School (JIS). Kasus di lembaga pendidikan berkelas ini sempat mengejutkan berbagai pihak, pasalnya lembaga pendidikan yang bertujuan untuk mendidik anak secara beradab justru menjadi ajang kekerasan seksual pada anak.Jika di lembaga pendidikan saja bukan merupakan tempat yang aman, bagaimana dengan anakanak rentan yang hidup tanpa pengawasan? Tentu fakta yang cukup memilukan ini harus menjadi perhatian kita semua.

Survey kekerasan terhadap anak (SKTA) tahun 2013 yang diselenggarakan oleh Kementerian Sosial juga menunjukkan kondisi yang kurang menggembirakan. Survey yang ditujukan untuk mengetahui data prevalensi nasional kekerasan (fisik, emosional, dan seksual) maupun pengetahuan mereka terhadap layanan tersebut dilakukan dengan responden yang berjumlah 11.250 anak laki-laki dan perempuan. Survey tersebut mencakup kejadian baru-baru ini (usia 13-17 tahun) dengan kejadian pada 12 bulan terakhir dan pengalaman seumur hidup (trauma) pada orang dengan usia 1824 tahun yang menyangkut kejadian sebelum usia 18 tahun. Survey tersebut dilakukan pada 25 provinsi, 108 kabupaten/kota, dan 125 kecamatan.

\section{Prevalensi Kekerasan}

Pada SKTA beberapa bentuk kekerasan pada anak yang disurvey sebagai berikut: Pertama, Kekerasan Seksual. Kekerasan seksual diindikasikan dengan adanya sentuhan secara seksual tanpa izin, percobaan hubungan seksual, hubungan seksual dengan paksaan secara fisik, dan hubungan seksual dengan paksaan di bawah pengaruh atau kekuasaan. Kedua, Kekerasan Fisik. Kekerasan ini menyangkut pengalaman seseorang ketika pernah ditonjok, ditendang, dicambuk atau dipukul dengan benda, dicekik, dibekap, ditenggelamkan atau dibakar, dengan sengaja. Termasuk diancam dengan pisau atau senjata lainnya. Ketiga, Kekerasan Emosional. Kekerasan emosional berkaitan dengan pengalaman seseorang ter- 
hadap orang tua atau pengasuh yang pernah mengatakan tidak disayang atau tidak pantas disayang; tidak pernah dilahirkan atau mati saja, dihina dan direndahkan.

Untuk mengetahui ketiga bentuk kekerasan tersebut, SKTA menggunakan dua pendekatan. Pertama, recent experience (pengalaman yang baru saja terjadi). Respondennya adalah anak usia 13-17 tahun yang mengalami kekerasan fisik, emosional dan seksual dalam 12 bulan terakhir. Kedua, lifetime experience (pengalaman seumur mengalaminya. hidup). Respondennya remaja usia 18-24 tahun yang mengalami kekerasan fisik, emosional dan seksual sebelum berusia 18 tahun.

Pendekatan recent experience anak lakilaki yang mengalami kekerasan fisik diperkirakan berjumlah tiga juta anak atau satu dari empat anak mengalami kekerasan fisik. Pada kekerasan emosional, diperkirakan 1,4 juta anak laki-laki atau 1 dari 8 anak pernah mengalaminya. Sedangkan dalam konteks kekerasan seksual, diperkirakan 900 ribu anak laki-laki atau satu dari 12 anak pernah

Tabel 1

Prevalensi Kekerasan terhadap Anak dengan pendekatan Recent Experience

\begin{tabular}{l|l|l}
\hline \multirow{2}{*}{ Kategori Kekerasan } & \multicolumn{2}{c}{ Estimasi Jumlah Kekerasan } \\
\cline { 2 - 3 } & \multicolumn{1}{|c}{ Laki-Laki } & \multicolumn{1}{c}{ Perempuan } \\
\hline Fisik & 3 juta (1 dari 4 anak) & 1,5 juta (1 dari 7 anak) \\
\hline Emosional & 1,4 juta (1 dari 8 anak) & 1,2 juta (1 dari 9 anak) \\
\hline Seksual & 900 ribu (1 dari 12 anak) & 600 ribu (1 dari 19 anak) \\
\hline
\end{tabular}

Sumber: SKTA (2013)

Pada anak perempuan, diperkirakan 1,5 juta anak atau satu dari tujuh anak mengalami kekerasan fisik. Dalam kekerasan emosional, diperkirakan ada 1,2 juta atau satu dari sembilan anak perempuan mengalami kekerasan emosional. Pada kekerasan seksual, diperkirakan ada 600 ribu anak atau satu dari 19 anak perempuan mengalami kekerasan (lihat tabel 1).

Pendekatan lifetime experience remaja yang mengalami kekerasan fisik berjumlah sekitar 5,7 juta atau dua dari lima remaja persebelum 18 tahun (lihat Tabel 2). nah mengalaminya. Kekerasan emosional pada anak laki-laki diperkirakan ada 1,8 juta atausatu dari delapan remaja pernah mengalaminya. Pada kekerasan seksual diperkirakan 1,1 juta atau satu dari 13 anak pernah mengalaminya ketika masih berusia sebelum 18 tahun. Pada anak perempuan diperkirakan 1,4 juta atau satu dari 10 anak pernah mengalami kekerasan fisik. Pada kekerasan emosional ada 700 ribu atau 1 dari 22 remaja pernah mengalaminya. Terakhir dalam hal kekerasan seksual, 800 ribu atau 1 dari 18 anak pernah mengalaminya ketika masih berusia

Tabel 2

Prevalensi Kekerasan terhadap Anak dalam Kategori Lifetime Experience

\begin{tabular}{l|l|l}
\hline \multirow{2}{*}{ Kategori Kekerasan } & \multicolumn{1}{c}{ Estimasi Jumlah Kekerasan } \\
\cline { 2 - 3 } & \multicolumn{1}{|c}{ Laki-Laki } & \multicolumn{1}{c}{ Perempuan } \\
\hline Fisik & 5,7 juta (2 dari 5 remaja) & 1,4 juta (1 dari 10 remaja) \\
\hline Emosional & 1,8 juta (1 dari 8 remaja) & 700 ribu (1 dari 22 remaja) \\
\hline Seksual & 1,1 juta (1 dari 13 anak) & 800 ribu (1 dari 18 anak) \\
\hline
\end{tabular}

Sumber: SKTA (2013)

Menarik dicermati bahwa jumlah kekerasan yang menimpa pada anak lakilaki lebih tinggi daripada anak perempuan.
Sebagaimana dijelaskan sebelumnya, salah satu faktor yang menjadi penyebabnya adalah kontrol ataupun pengawasan terhadap anak perempuan justru besar sehingga lebih 
protektif. Jumlah di atas sesungguhnya bisa membengkak karena anak laki-laki biasanya mempunyai perasaan malu untuk mengungkapkan pengalaman bahwa dirinya pernah menjadi korban kekerasan. Sehingga data semacam ini bisa jadi mirip dengan "gunung es" di tengah lautan, kecil di permukaan, tetapi bisa sangat besar dan luas di dalamnya.

\section{Pelaku Kekerasan Anak}

Pelaku kekerasan terhadap anak banyak dilakukan oleh orang-orang terdekat. Memang ada pelaku dari pihak asing, tapi jumlahnya lebih sedikit. Pelaku kekerasan secara fisik dikategorikan menjadi dua kelompok yakni keluarga dan masyarakat. Dari pihak keluarga, 38,23 persen dilakukan oleh ayah dengan korban anak laki-laki dan 35,53 persen pada anak perempuan. Pelaku seorang ibu 26,18 persen dengan korban anak laki-laki dan 11,03 pada anak perempuan. Yang cukup tinggi pelaku kekerasan dari pihak keluarga ini dilakukan oleh kerabat lain terutama pada anak perempuan 53,44 persen dan dengan korban yang lebih kecil nada anak laki-laki (35.59 nersen).

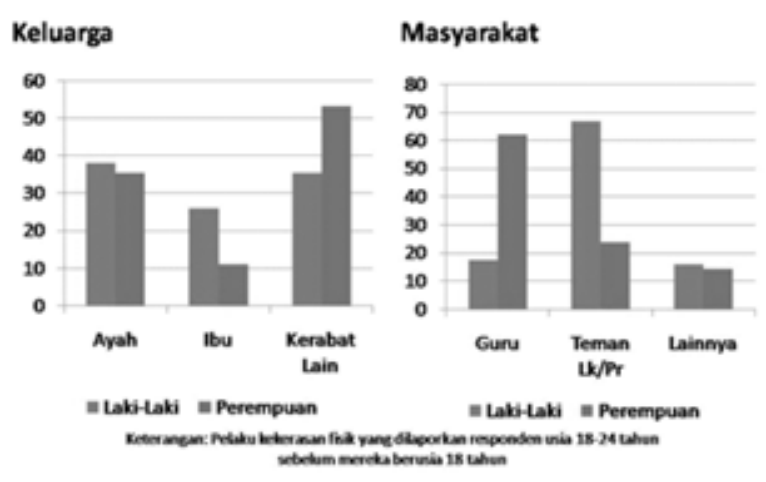

Gambar 1
Diagram Pelaku Kekerasan Usia 18-24

Selain pihak keluarga, masyarakat juga menyumbang prosentase yang tidak kalah besar sebagai pelaku kekerasan terhadap anak. Seorang guru yang dipercaya sebagai pendidik anak justru memiliki prosentase yang cukup besar sebagai pelaku kekerasan pada anak (62,05 persen pada laki-laki dan 17,47 persen pada perempuan). Sementara teman sepermainan baik di masyarakat maupun sekolah juga didapat prosentase yang tidak kalah tinggi (66,69 persen pada anak laki-laki dan 23,63 persen pada anak perempuan). Terakhir, pihak lainnya dari masyarakat dengan prosentase 15,84 persen terhadap anak laki-laki dan 14,32 persen pada anak perempuan (lihat gambar 1). Dalam kekerasan seksual setidaknya ada 4 kelompok tertinggi yang berperan sebagai pelaku.

Pertama, teman laki-laki yang melakukan kekerasan terhadap anak laki-laki lainnya (usia 13-17 dan 18-24 tahun masing-masing sebesar 43,83 dan 10,18 persen) dan terhadap anak perempuan (13-17 dan 18-24 tahun masingmasing sebesar 32,03 dan 22,27 persen). Kedua, pacar laki-laki yang melakukan kekerasan kepada anak lelaki lainnya (usia 13-17 dan 18-24 tahun masing-masing sebesar 13,16 dan 13,88 persen) dan terhadap anak perempuan (usia 13-17 dan 18-24 tahun masing-masing sebesar 19,73 dan 30,15 persen). Ketiga, orang asing yang melakukan kekerasan terhadap anak laki-laki (usia 13-17 dan 18-24 tahun masing-masing sebesar 1,34 dan 5,24 persen) dan terhadap anak perempuan (usia 13-17 dan 18-24 tahun masing-masing sebesar 20,12 dan 20,97 persen). Keempat, tetangga laki-laki yang melakukan kekerasan khususnya kepada anak perempuan (usia 13-17 dan 18-24 tahun masing-masing sebesar 9,29 dan 6,10 persen)

(lihat tabel 3).

Tabel3

Pelaku Kekerasan Seksual pada Anak

\begin{tabular}{l|l|l|l|l}
\hline \multirow{2}{*}{ Pelaku Kekerasan Seksual } & \multicolumn{2}{c|}{ Laki-Laki } & \multicolumn{2}{c}{ Perempuan } \\
\cline { 2 - 5 } & 13-17 Tahun & $\mathbf{1 8 - 2 4}$ Tahun & 13-17 Tahun & 18-24 Tahun \\
\hline Pacar Laki & 13,16 & 13,88 & 19,73 & 30,15 \\
\hline Suami & & & & 11,52 \\
\hline Ayah Tiri & & 4,79 & & \\
\hline
\end{tabular}


Lanjutan Tabel 3

\begin{tabular}{l|l|l|l|l}
\hline \multirow{2}{*}{\multicolumn{1}{c}{ Pelaku Kekerasan Seksual }} & \multicolumn{2}{c|}{ Laki-Laki } & \multicolumn{2}{c}{ Perempuan } \\
\cline { 2 - 5 } & $\mathbf{1 3 - 1 7}$ Tahun & $\mathbf{1 8 - 2 4}$ Tahun & $\mathbf{1 3 - 1 7}$ Tahun & $\mathbf{1 8 - 2 4}$ Tahun \\
\hline Saudara Laki & & & 13,64 & \\
\hline Guru Laki & & 6,51 & & \\
\hline Polisi Laki & & & & 3,54 \\
\hline Laki Tetangga & & & 9,29 & 6,10 \\
\hline Teman laki & 43,83 & 10,18 & 32,03 & 22,27 \\
\hline Laki Asing & 1,34 & 5,24 & 20,12 & 20,29 \\
\hline Pacar Perempuan & 10,75 & 29,21 & & \\
\hline Perempuan Tetangga & 2,24 & & & \\
\hline Teman Perempuan & 21,98 & 21,04 & 1,09 & \\
\hline Perempuan Asing & 3,45 & 8,44 & & \\
\hline Perempuan Lainnya & 3,04 & & & \\
\hline Tidak Tahu & & & & 5,47 \\
\hline Jumlah & $100 \%$ & $100 \%$ & $100 \%$ & $100 \%$ \\
\hline
\end{tabular}

Sumber: (SKTA, 2013)

Data di atas menampilkan hal menarik. Pacar laki, teman laki, dan laki asing banyak melakukan kekerasan terhadap perempuan usia 18-24 tahun. Pertanyaannya, mengapa laki-laki banyak melakukan kekerasan? Mengacu pada temuan Fullu (2014), yang menunjukkan bahwa lebih dari $70 \%$ korban kekerasan akan menjadi pelaku kekerasan di kemudian hari, maka data ini menegaskan bahwa karena anaklaki-laki lebih sering mengalami kekerasan fisik, emosional dan seksual, maka anak laki-laki lebih berpeluang menjadi pelaku kekerasan di kemudian hari.

\section{Pengetahuan tentang Layanan}

Intensitas kekerasan terhadap anak dipengaruhi oleh pengetahuan mereka terhadap layanan khususnya yang berkaitan dengan perlindungan anak. Semakin tinggi pengetahuan terhadap layanan ini maka dampak traumatik dapat diminimalisir, sebaliknya ketidaktahuan terhadap layanan bisa mengakibatkan korban akan semakin terpuruk pada perasaan traumatik yang berlarut-larut. Sayangnya, mayoritas anak lakilaki maupun perempuan tidak mengetahui adanya layanan tersebut. Sebanyak 78,7 persen anak laki-laki tidak mengetahui sedangkan sisanya 21,3 persen mengetahui. Pada anak perempuan 85,1 persen tidak mengetahui dan sisanya 12,7 persen mengetahui

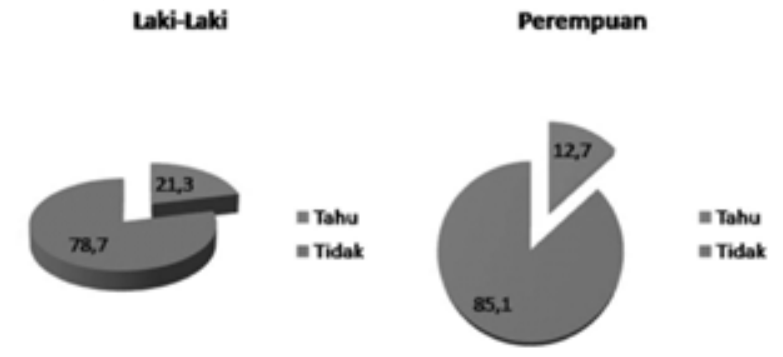

Keterangan: Pengetahuan tentanglayanan menurut responden usia 13-17 tahun yangmengalami kekerasan FISIK dalm 12 bulan terakhir

Gambar 2

Pengetahuan Anak terhadap Layanan Sumber: (SKTA, 2013)

\section{Respon Pekerjaan Sosial}

Pekerjaan sosial merupakan profesi yang relevan untuk mengatasi krisis kekerasan anak. Sebagaimana masalah kesehatan ditangani oleh dokter, pendidikan oleh guru, maka masalah sosial ditangani oleh pekerja sosial. Pekerjaan sosial memang bertujuan untuk menolong individu, kelompok dan masyarakat dalam meningkatkan atau memperbaiki kapasitas mereka agar berfungsi sosial dan menciptakan kondisi-kondisi masyarakat yang kondusif untuk mencapai tujuan tersebut (Zastrow, 1999).

Dalam melakukan pertolongan ini pekerja sosial didasari oleh kerangka pengetahuan (body of knowledge), kerangka keahlian (body of skills) dan kerangka nilai (body of 
values) yang secara integratif membentuk profil dan pendekatan pekerjaan sosial. Ini yang sekaligus menjadi argument akademis kenapa kekerasan anak paling tepat ditangani oleh profesi pekerjaan sosial. Respon pekerjaan sosial terhadap masalah sosial yang kritis seperti kekerasan pada anak sangat diperlukan karena membutuhkan penanganan yang segera, serius dan berorientasi pada penyelesaian masalah. Ada beberapa catatan penting berkait kekerasan pada anak sebagaimana diungkap di atas.

Pertama, anak-anak kita sesungguhnya rentan terhadap kekerasan fisik, emosional maupun seksual. Kerentanan ini justru lebih banyak terjadi pada anak laki-laki dibandingkan dengan anak perempuan. Kedua, pelaku kekerasan ternyata berasal dari orangorang terdekat yang dikenal oleh korban. Bukan justru berasal dari luar dan yang belum dikenal oleh korban, meskipun ada prosentasenya relatif kecil. Ketiga, korban kurang mengetahui dan memiliki akses terhadap layanan pada kasus kekerasan ini. Keempat, dampak kekerasan pada anak ini sangat luas karena tidak hanya berdampak pada korban,tetapi kepada keluarga maupun masyarakat. Kelima, atas berbagai problem kekerasan ini diperlukan sistem perlindungan sosial yang terintegrasi, mencakup pencegahan, respon dan rehabilitasi sosial yang komprehensif.

Perlindungan anak perlu terus dikampanyekan sebagai respon terhadap kasus kekerasan anak. Secara formal, perlindungan anak telah menjadi amanah konstitusi. Undang-Undang Nomor 23 tahun 2002 tentang perlindungan anak (pasal 1 angka 2) telah menyebutkan secara eksplisit mengenai perlunya perlindungan terhadap anak.Perlindungan anak yang dimaksud adalah segala aktivitas untuk melindungi anak dan hak-haknya agar dapat hidup, tumbuh, berkembang, dan berpartisipasi secara optimal sesuai dengan harkat dan martabat kemanusiaan serta mendapat perlindungan, kekerasan, dan diskriminasi.

Selama ini berbagai pihak memang tidak tinggal diam menyangkut problem kekeras- an terhadap anak. Terutama pemerintah melalui Kementerian Sosial telah melahirkan program misalnya Program Kesejahteraan Sosial Anak (PKSA) yang telah direalisasikan sejak tahun 2009 dan telah melayani 175.611 anak pertahunyang memungkinkan mereka dalam memenuhi kebutuhan dasar. PKSA ini juga didukung antara lain: tenaga professional (Satuan Bakti Pekerja Sosial/ Sakti Peksos) yang berjumlah 670 orang, 25 Rumah Perlindungan Sosial Anak (RSPA),15 telephone sahabat anak (TESA), 12 Tim Reaksi Cepat (TRC) di pusat dan 33 Provinsi, dan 28 Lembaga Perlindungan Anak (LPA).

Untuk menciptakan sistem perlindungan anak yang berkelanjutan diperlukan paradigma penanganan yang tidak hanya mencakup aspek pencegahan yang bertumpu pada konsep kesejahteraan anak. Tetapi juga mencakup aspek rehabilitatif karena pada wilayah ini dihadapkan pada anakanak yang memiliki resiko tinggi. Jika hal ini bisa dilakukan maka kita telah memiliki kerangka perlindungan anak yang berbasis pada "continuum of care" yakni perlindungan anak yang menyeluruh karena berbasis pada perawatan anak secara kontinu (berkelanjutan) (gambar 3).

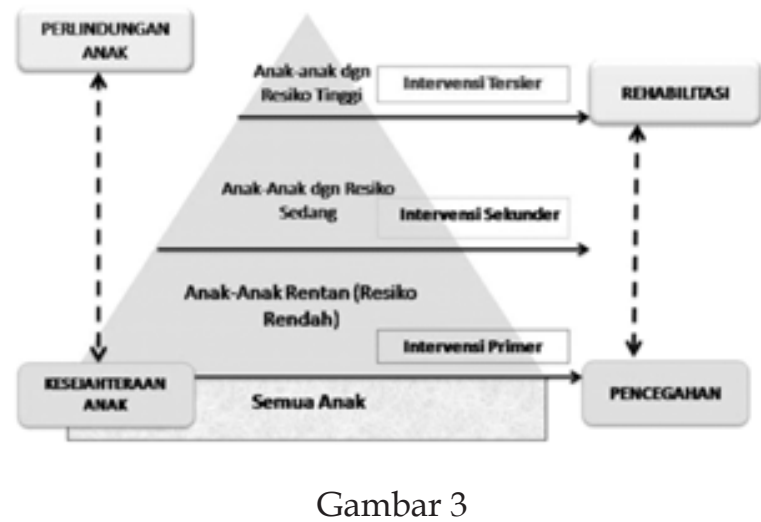

Kerangka "continuum of care" Perlindungan Anak Sumber: UNICEF (2012)

Kerangka "continuum of care" ini memang harus membedakan orientasi penanganan disesuaikan dengan kondisi anak. Misalnya anak yang dengan resiko kerentanan yang rendah tentu penanganannya harus berbeda dengan anak dengan resiko kerentanan yang lebih besar. Analoginya, jika orang 
mempunyai penyakit kronis maka obatnya tidak cukup dengan obat generik. Obat harus disesuaikan dengan jenis penyakitnya. Kementerian Sosial mulai tahun 2014 memberikan perhatian yang khusus terutama kepada anak-anak yang membutuhkan perlindungan khusus (AMPK) dengan resiko kerentanan yang tinggi. Anak dengan kategori AMPK ini seperti Anak yang Berhadapan dengan Hukum $(\mathrm{ABH})$, Anak dengan Disabilitas (ADK), Balita Terlantar dan Anak Terlantar. Perhatian khusus perlu diberikan karena anak-anak dalam kategori ini memerlukan penanganan yang segera dan tidak bisa disamakan dengan anak-anak dengan resiko kerentanan yang rendah.

Tidak hanya pemerintah, masyarakat dari profesi lain juga dituntut untuk berkontribusi dalam kasus kekerasan anak. Apalagi, kasus kekerasan banyak menyangkut disiplin ilmu lain. Misalnya kasus ABH berhubungan dengan bidang hukum, anak trauma dengan psikologi dan seterusnya.Di sinilah diperlukan penanganan multi sektor dalam menghadapi kekerasan pada anak (lihat gambar 4).

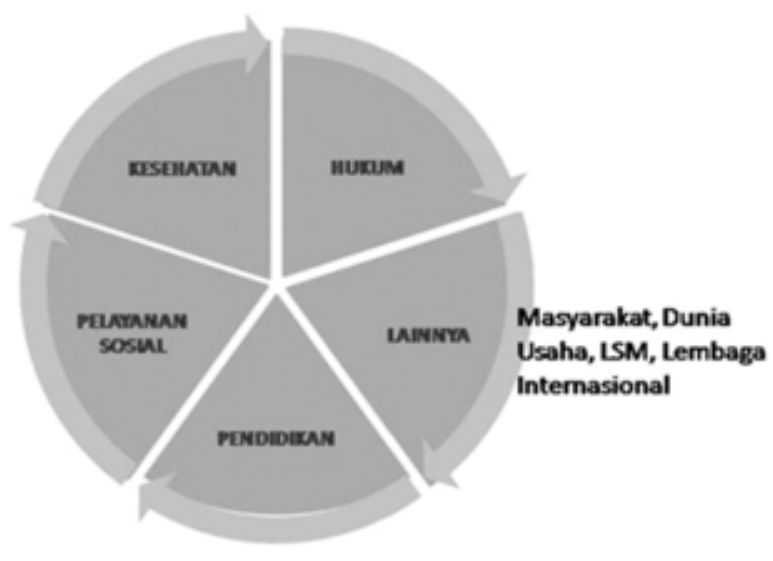

Gambar 4

Penanganan Multi Sektor

Beberapa kasus kekerasan terhadap anak menunjukkan perlu adanya peran sektor lain untuk mendukung terpenuhinya hak-hak anak. Seorang anak yang menjadi korban kekerasan seksual misalnya, untuk melengkapi berita acara pemeriksaan di kepolisian pada saat melaporkan kejadian kasus dia harus dilakukan visum. Visum ini tentu membutuhkan biaya yang tidak kecil sehingga akan memberatkan, apalagi jika korban berasal dari keluarga tidak mampu. Bilakeluargakorbanyangharusmenanggung, maka ibarat pepatah"sudah jatuh tertimpa tangga." Dia harus menanggung penderitaan yang berlipat ganda. Maka dinas kesehatan setempat dapat berperan untuk menjamin biaya visum tersebut. Demikian pula pihak lainnya yang juga harus berperan secara bersama-sama dalam menangani masalah kekerasan terhadap anak ini.

\section{SIMPULAN}

Kekerasan anak bukan hanya persoalan nasional namun juga masalah global. Bahkan di negara-negara maju yang menjunjung tinggi hak-hak asasi manusia seperti halnya Amerika Serikat, kekerasan terhadap anak telah menjadi isu umum. Maka kekerasan anak sesungguhnya telah menjadi masalah bersama sehingga seluruh pihak harus menyadari bahwa perlindungan terhadap anak adalah sesuatu yang sangat mendesak. Perlindungan anak ini bisa diterapkan oleh seluruh warga masyarakat dengan meningkatkan dan menjamin lingkungan yang aman bagi anak. Apalagi beberapa kasus menunjukkan pelaku kekerasan bukanlah orang asing yang tidak mengenal korban akan tetapi ternyata adalah dari pihak-pihak terdekat seperti keluarga, saudara dekat maupun tetangga yang telah mengenal korban.

Kasus-kasus kekerasan terhadap anak telah menunjukkan fakta baru bahwa kekerasan terhadap anak ternyata lebih banyak terjadi pada anak laki-laki dibandingkan dengan anak perempuan.Ini menunjukkan perlunya penguatan pengawasan dan pendidikan keluarga terhadap anak misalnya, penguatan pola pengasuhan keluarga yang baik perlu terus digalakkan karena pengasuhan anak yang paling terbaik tetap berada di lingkungan keluarga terdekat, khususnya keluarga inti, bukan di lembaga seperti di panti asuhan.

Pekerjaan sosial sebagai profesi kemanusiaan harus bekerjasama dengan pegiat 
di bidang pendidikan dan hukum, termasuk dengan media massa dan masyarakat yang lebih luas dalam memberikan perlindungan anak yang rentan. Tanpa adanya dukungan seluruh pihak maka penanganan terhadap anak hanya bersifat ad hoc dan parsial. Pada bidang hukum misalnya, penanganan terhadap pelaku maupun korban kekerasan perlu menegakkan prinsip-prinsip dan hakhak anak yang telah diatur dalam perundangundangan yang berlaku di Indonesia, seperti UU No. 23 Tahun 2002 Tentang Perlindungan Anak. Jika hal ini bisa dilakukan maka sistem perlindungan anak dapat menjadi solusi atas berbagai kasus kekerasan yang sangat merugikan anak sebagai generasi penerus bangsa ini.

\section{DAPTAR PUSTAKA}

Finkelhor, D et. al,. 2009.Children's Exposure to Violence: A Comprehensive National Survey. Washington, DC: U.S. DOJ, OJP, OJJDP, CDC.

Fulu, Emma. 2014. “Links Between VAC \& VAW: Implications for Prevention,"
Makalah dipresentasikan di "Global Meeting on Violence against Children from Research to Action: Advancing Prevention and Response to Violence against Children," Ezulwini, Swaziland 28-30 May 2014.

Kementerian Sosialet.al,. 2013.Survey Terhadap Kekerasan Anak (SKTA) tahun 2013. Jakarta: Kemensos RI.

Lapian, L.M. Gandhi dan Hetty A. Geru (editor).2006.Trafiking Perempuan dan Anak Penanggulangan Komprehensif Studi Kasus Sulawesi Utara.Jakarta: Yayasan Obor Indonesia.

Sunarto.2009. Televisi, Kekerasan dan Perempuan. Jakarta: PT Kompas Media Nusantara.

Undang-Undang Perlindungan Anak Nomor 23 tahun 2002 tentang Perlindungan Anak.

UNICEF. 2014. "Cerita dari Indonesia" dari www.unichef.org/indonesia/.../ indonesiahistory.

Zastrow, Charles H. 1999. The Practice of Social Work.Pacific Grove: Brook/Cole. 